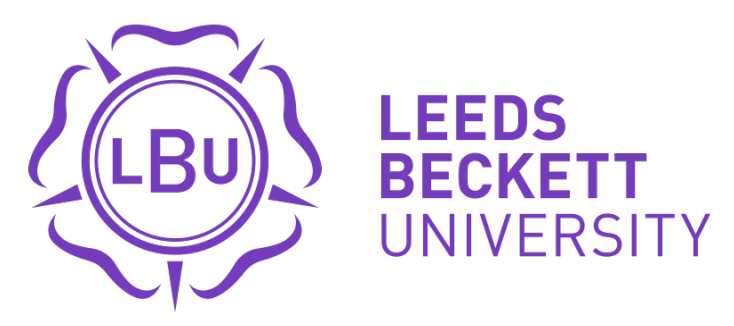

Citation:

Hind, K (2016) Sedentary Time and Central Adiposity in Children. Journal of Clinical Densitometry, 19 (3). pp. 264-265. ISSN 1559-0747 DOI: https://doi.org/10.1016/j.jocd.2016.04.012

Link to Leeds Beckett Repository record:

https://eprints.leedsbeckett.ac.uk/id/eprint/2594/

Document Version:

Article (Accepted Version)

The aim of the Leeds Beckett Repository is to provide open access to our research, as required by funder policies and permitted by publishers and copyright law.

The Leeds Beckett repository holds a wide range of publications, each of which has been checked for copyright and the relevant embargo period has been applied by the Research Services team.

We operate on a standard take-down policy. If you are the author or publisher of an output and you would like it removed from the repository, please contact us and we will investigate on a case-by-case basis.

Each thesis in the repository has been cleared where necessary by the author for third party copyright. If you would like a thesis to be removed from the repository or believe there is an issue with copyright, please contact us on openaccess@leedsbeckett.ac.uk and we will investigate on a case-by-case basis. 


\section{Sedentary time and central adiposity in children}

There is currently a global epidemic of obesity, with a recent pooled analysis indicating that over the last forty years, the number of obese people worldwide has risen from 105 million to 641 million (1). The global economic and clinical burden is substantial, with pressures not only for treating obesity per se, but also for treating the associated myriad of non-communicable diseases such as type 2 diabetes, fatty liver, cardiovascular disease, osteoarthritis and cancer. Importantly, childhood obesity is a strong predictor of adult obesity (2), and over the last few decades, the prevalence in children has increased significantly in developed countries; almost one quarter of boys and girls were overweight or obese in 2013 (3). In developing countries childhood overweight and obesity is also increasing, with figures currently standing at around $13 \%(3)$. These statistics suggest that we are facing one of the biggest societal health challenges to date.

Low global levels of physical activity are among the factors fuelling concern, for example, over $80 \%$ of adolescents do not take part in the recommended 60 minutes of moderate-vigorous physical activity per day (4). With such shortfalls in meeting exercise guidelines, focus is now moving towards sedentary time, which is defined as behavior that requires little energy expenditure and which occurs in a sitting or reclined position (e.g. while watching television, surfing the net or spending time on smart phones). This is a topic of prevailing interest and is emerging as a distinct risk factor for obesity and metabolic disease in children as well as adults. Sedentary time is associated with a higher body mass index (BMI) and an amass of body fatness in adults (5). Research to improve our understanding of this trajectory is important especially given the accumulating evidence that adipose tissue is directly instigated in the systemic inflammation underlying numerous diseases (6-7).

In this issue of the Journal of Clinical Densitometry, $\mathrm{xxxx}$ et al, obtained dual energy X-ray absorptiometry (DXA) measures of adiposity in eighty seven children aged 10 years and explored relationships with accelerometer-measured sedentary time. The authors report positive associations of sedentary time with total body and android fat mass. The association with android fat in particular is highlighted as important because of the known relationships between central adiposity and meta-inflammation - centrally-located adipose tissue is an active and rich source of pro-inflammatory adipokines. The chronic inflammatory response to obesity is characterised by significant adipokine production and activation of several pro-inflammatory signalling pathways, resulting in the induction of numerous biological markers of inflammation such as interleukin- 6 and tumour necrosis factor-alpha. Meta-inflammation is thought to be the primary link between obesity and chronic disease. Even in children and adolescents, higher abdominal fat mass is associated with higher cardiovascular and type 2 diabetes risk (8-9). The significant association between the children's sedentary time and central adiposity provides evidence for public health interventions to get children moving, regardless of whether or not the activity performed is moderate or vigorous in intensity. The authors rightly call for public health policies on childhood obesity, to address sedentary time in addition to the current focus on moderate to vigorous physical activity. In theory, sedentary behaviours are easily modified (e.g. removing a TV or a computer from the bedroom), although others may require more intense behavioral interventions (e.g., increasing habitual physical activity to meet current guidelines). The research team used accelerometry to quantify sedentary time and time spent in physical activity, and this is regarded as an objective measure, improving on self-report measures. While accelerometers are able to provide data related to movement/nonmovement patterns for the whole day, they are not able to discriminate between different postures (e.g. standing still versus sitting still), or types of sedentary behaviors (e.g. reading versus watching TV). Future research exploring the variations of sedentary behaviour and the related health effects, would be valuable to help pinpoint targets for intervention.

Another important finding of this study is that associations between levels of physical activity and body composition were hidden using BMI percentile as an outcome compared to percentage body fat measured by DXA. This was particularly the case for boys, highlighting the importance of sex-specific analysis. The authors acknowledge that while BMI percentile is easy to assess by measuring height and weight, it cannot distinguish body fatness and is best utilised as a screening tool. Indeed, DXA is advantageous in that fat mass can be readily quantified for the whole body as well as for regions known to be associated with detrimental health outcomes (android and truncal regions). With a relatively low ionising radiation dose, in cases of obesity, it could be argued that the benefits of DXA scanning would outweigh any risks. For instance, enabling the early detection of unhealthy fat deposition so that strategies to prevent future obesity and the associated systemic inflammation can be initiated. In adults, body composition densitometry is indicated for obese individuals 
undergoing weight loss regimes where a large amount of weight loss is expected or for cardio-metabolic risk stratifying. In children, total body DXA is currently only indicated for chronic conditions associated with malnutrition and muscle and skeletal deficits, and not for evaluation of obesity (10).

In summary, this article demonstrates a link between sedentary time and central adiposity in children, and highlights a need for future prospective research into fat accumulation during growth with exploration of different forms of sedentary behaviour. Substantiated by previous work in the field (11), and given current global obesity projections, it is timely that attention is given to minimising sedentary time in children as one strategy toward reducing the future obesity burden.

\section{References}

1. Trends in adult body-mass index in 200 countries from 1975 to 2014: a pooled analysis of 1698 populationbased measurement studies with $\mathbf{1 9 . 2}$ million participants. The Lancet 2016; 387:1377-1396

2. Nishtar S, Gluckman P, Armstrong T. Ending childhood obesity: a time for action. The Lancet. 2016; Feb 27;387(10021):825-7

3. Ng M, Fleming T, Robinson M, Thomson B, Graetz N, Margono C, Mullany EC, Biryukov S, Abbafati C, Abera SF, Abraham JP. Global, regional, and national prevalence of overweight and obesity in children and adults during 1980-2013: a systematic analysis for the Global Burden of Disease Study 2013. The Lancet. 2014; Sep 5;384(9945):766-81

4. Hallal PC, Andersen LB, Bull FC, Guthold R, Haskell W, Ekelund U, Lancet Physical Activity Series Working Group. Global physical activity levels: surveillance progress, pitfalls, and prospects. The Lancet. 2012; Jul 27 :247-57

5. Wijndaele K, Healy GN, Dunstan DW, Barnett AG, Salmon J. Increased cardiometabolic risk is associated with increased TV viewing time. Med Sci Sports Exerc 2010; 42: 1511

6. Esser N, Legrand-Poels S, Piette J, Scheen AJ, Paquot N. Inflammation as a link between obesity, metabolic syndrome and type 2 diabetes. Diabetes research and clinical practice. 2014 Aug 31;105(2):141-50

7. Iyengar NM, Hudis CA, Dannenberg AJ. Obesity and cancer: local and systemic mechanisms. Annual Review of Medicine. 2015; Jan 14;66:297-309

8. Gishti O, Gaillard R, Durmus B, Abrahamse M, van der Beek EM, Hofman A, Franco OH, de Jonge LL, Jaddoe VW. BMI, total and abdominal fat distribution, and cardiovascular risk factors in school-age children. Pediatric research. 2015; Feb 9;77(5):710-8

9. He F, Rodriguez-Colon S, Fernandez-Mendoza J, Vgontzas AN, Bixler EO, Berg A, Kawasawa YI, Sawyer MD, Liao D. Abdominal Obesity and Metabolic Syndrome Burden in Adolescents-Penn State Children Cohort Study. Journal of Clinical Densitometry. 2015; Jan 31;18(1):30-6

10. Official Positions of the International Society for Clinical Densitometry 2015 Update. http://www.iscd.org/official-positions/2015-iscd-official-positions-adult/ accessed 15.04.2016.

11. LeBlanc A, Katzmarzyk PT, Barreira TV, Broyles ST, Chaput JP, Church TS, Fogelholm M, Harrington DM. Hu G, Kuriyan R, Kurpad A, Lambert EV, Maher C, Maia J, Matsudo V, Olds T, Onywera V, Samiento OL, Standage M, Tudor-Locke C, Zhao P, Tremplay MS. Correlates of Total Sedentary Time and Screen Time in 9-11 Year-Old Children around the World: The International Study of Childhood Obesity, Lifestyle and the Environment. PLOS One 2015; June 11 